\title{
Anti-amyloid aggregation activity of novel carotenoids: implications for Alzheimer's drug discovery
}

\author{
Johant Lakey-Beitia, ${ }^{1,2}$ Deborah \\ Doens, ${ }^{2,3} \mathrm{D}$ Jagadeesh Kumar, ${ }^{4}$ \\ Enrique Murillo, ${ }^{5}$ Patricia L \\ Fernandez, ${ }^{3} \mathrm{KS}$ Rao, ${ }^{6}$ Armando \\ A Durant-Archibold ${ }^{1,5}$ \\ 'Center for Biodiversity and Drug \\ Discovery, Instituto de Investigaciones \\ Científicas y Servicios de Alta Tecnología \\ (INDICASAT AIP), Panama, Republic of \\ Panama; ${ }^{2}$ Department of Biotechnology, \\ Acharya Nagarjuna University, Guntur, India; \\ ${ }^{3}$ Center for Molecular and Cellular Biology \\ of Diseases, Instituto de Investigaciones \\ Científicas y Servicios de Alta Tecnología \\ (INDICASAT AIP), Panama, Republic of \\ Panama; ${ }^{4}$ Department of Biotechnology, \\ Sir M Visvesvaraya Institute of Technology, \\ Bangalore, India; ${ }^{5}$ Department of \\ Biochemistry, College of Natural, Exact \\ Sciences and Technology, University of \\ Panama, Panama, Republic of Panama; \\ ${ }^{6}$ Center for Neuroscience, Instituto de \\ Investigaciones Científicas y Servicios de \\ Alta Tecnología (INDICASAT AIP), Panama, \\ Republic of Panama
}

This article was published in the following Dove Press journal:

Clinical Interventions in Aging

15 May 2017

Number of times this article has been viewed

\begin{abstract}
Alzheimer's disease (AD) is the leading cause of dementia, affecting approximately 33.5 million people worldwide. Aging is the main risk factor associated with AD. Drug discovery based on nutraceutical molecules for prevention and treatment of AD is a growing topic. In this sense, carotenoids are phytochemicals present mainly in fruits and vegetables with reported benefits for human health. In this research, the anti-amyloidogenic activity of three carotenoids, cryptocapsin, cryptocapsin-5,6-epoxide, and zeaxanthin, was assessed. Cryptocapsin showed the highest bioactivity, while cryptocapsin-5,6-epoxide and zeaxanthin exhibited similar activity on anti-aggregation assays. Molecular modeling analysis revealed that the evaluated carotenoids might follow two mechanisms for inhibiting $A \beta$ aggregation: by preventing the formation of the fibril and through disruption of the $A \beta$ aggregates. Our studies provided evidence that cryptocapsin, cryptocapsin-5,6-epoxide, and zeaxanthin have anti-amyloidogenic potential and could be used for prevention and treatment of AD.
\end{abstract}

Keywords: Alzheimer's disease, aging, anti-amyloidogenic activity, cryptocapsin, cryptocapsin5,6-epoxide, zeaxanthin

\section{Introduction}

Alzheimer's disease (AD) is the leading cause of dementia, affecting approximately 33.5 million people worldwide, with 5 million new cases every year. ${ }^{1,2}$ Aging is the main risk factor associated with $\mathrm{AD}$, and the prevalence of the disease has been estimated from $0.6 \%$ to $8.4 \%$ in people at ages between 65 and 85 years. ${ }^{3}$ Clinical features of this neurodegenerative condition include slow loss of memory and reasoning skills, speech abnormalities, and disorientation. ${ }^{3-5}$ The disease culminates in the complete custodial care of the patient and finally death, which is usually caused by pneumonia. ${ }^{3}$ The presence of intracellular neurofibrillary tangles and extracellular $\mathrm{A} \beta$ senile plaques in the brain is a pathological feature of $A D{ }^{6,7} \mathrm{~A} \beta$ is produced by the cleavage at the beta site of the amyloid-beta precursor protein (APP) by $\beta$-secretase. This cleavage leads to the formation of a small soluble APP- $\beta$ and C-99 fragments, which in turn are broken down by the enzyme $\gamma$-secretase, generating an insoluble $A \beta_{42}$ peptide, which polymerizes and deposits in the brain as senile plaques. ${ }^{7,8}$ Metabolic imbalance produces increased quantities of $A \beta$, thus favoring the formation of amyloid fibrils in the brain, which leads to neuronal cell death. ${ }^{4} \mathrm{~A} \beta$ stimulates the production of neurotoxic reactive oxygen species and brain inflammation that contribute notably to the advancement of multifactorial AD. ${ }^{9,10}$ Consequently, $A \beta$ aggregates are significant targets in the development of new therapeutical approaches for AD. 
Several investigations have revealed that compounds present in food hold neuroprotective properties, and play a significant role in the prevention of different neurodegenerative disorders. ${ }^{11-15}$ Carotenoids are phytochemicals present in fruits, some of which (close to 50) are essential in human nutrition due to their provitamin A properties. ${ }^{16}$ Accumulating evidence indicates that these isoprenoid compounds prevent or ameliorate human diseases such as eye disorders, cancer, and cardiovascular diseases. ${ }^{16,17}$ Nevertheless, the effect on brain bioactivity of these compounds has been poorly studied, particularly in AD. ${ }^{15,18}$ Owing to the chemical nature of carotenoids and their ability to cross the brain membrane and accumulate in neural tissues, these compounds have great potential to act as functional agents for $\mathrm{AD}$ prevention and treatment. The physicochemical properties of carotenoids such as presence of keto $\kappa$-rings (eg, cryptocapsin and cryptocapsin-5,6-epoxide) and $\beta$-rings (eg, zeaxanthin) might provide to these compounds the potential to prevent the formation of $\mathrm{A} \beta$ aggregates, or to disrupt these aggregates. This paper provides data on the anti-amyloidogenic activity of carotenoids containing keto $\kappa$-rings and $\beta$-rings.

\section{Materials and methods Samples and isolation of carotenoid standards}

Pouteria sapota (mamey) was obtained from the metropolitan public market in Panama, while Aiphanes aculeata (corozo fruit) was collected directly from the tree. Carotenoid standards were extracted and isolated from the fruits according to recommended procedures. ${ }^{19,20}$ Five hundred grams of $P$. sapota pulp and $A$. aculeate were homogenized separately with $50 \mathrm{~g}$ of $\mathrm{NaHCO}_{3}$ and extracted exhaustively with acetone. A solution of $\mathrm{Et}_{2} \mathrm{O} / n$-hexane and distilled water were added to the acetonic extract. The organic phase was concentrated and dried over sodium sulfate $\left(\mathrm{Na}_{2} \mathrm{SO}_{4}\right)$, then diluted with $\mathrm{Et}_{2} \mathrm{O}$, and saponified with methanolic $\mathrm{KOH}$. The saponified mixture was then washed with water, concentrated, and dried over $\mathrm{Na}_{2} \mathrm{SO}_{4}$. The crude extract of each fruit was subjected to vacuum liquid chromatography using aluminum oxide (Brockmann grade III) as the stationary phase and increased percentages of ethyl ether in $n$-hexane as the eluent. All reagents and chemicals used for this research were of analytical grade.

\section{High performance liquid chromatography- diode array detection analysis}

Further purification of the carotenoids was achieved by high performance liquid chromatography-diode array detection on an 1100 HPLC system (Agilent, Santa Clara, CA, USA) equipped with a diode array detector and a quaternary pump. A YMC C30 column $(250 \times 10 \mathrm{~mm}, 5 \mu \mathrm{m})$ was used as the stationary phase. Elution of the compounds was done by means of two solutions (eluents): solution A consisting of a mixture $\mathrm{MeOH} / \mathrm{MTBE} / \mathrm{H}_{2} \mathrm{O}(81: 15: 4)$ and solution B consisting of a mixture of $\mathrm{MeOH} / \mathrm{MTBE} / \mathrm{H}_{2} \mathrm{O}$ (6:90:4). A linear gradient of $100 \%$ of solution A ( $0 \mathrm{~min})$ to $50 \%$ of solution $\mathrm{A}$ and $\mathrm{B}(45 \mathrm{~min})$ at $2 \mathrm{~mL} / \mathrm{min}$ was used.

\section{Carotenoid characterization}

Carotenoids were identified by nuclear magnetic resonance (NMR) and mass spectrometry (MS). ${ }^{1} \mathrm{H},{ }^{13} \mathrm{C}$ NMR spectra were recorded at $400\left({ }^{1} \mathrm{H}\right), 100 \mathrm{MHz}\left({ }^{13} \mathrm{C}\right)$ on an Eclipse $400 \mathrm{MHz}$ spectrometer (JEOL, Peabody, MA, USA). Chemical shifts $(\delta)$ were reported in parts per million from the residual solvent peak and coupling constant $(J)$ in Hz. Proton multiplicity is reported in singlet (s), doublet (d), triplet (t), quartet (quart), quintet (quint), septet (sept), multiplet (m), and broad (br). The molar mass for each compound was measured in a micrOTOF/QIII mass spectrometer (Bruker Daltonics, Billerica, MA, USA), in atmospheric chemical ionization (APCI)-positive mode, scanning from 200 to $700 \mathrm{~m} / \mathrm{z}$. A complete description of the carotenoid characterization by NMR and MS is described in Supplementary information.

\section{$A \beta_{42}$ aggregation assay}

The aggregation of $A \beta_{42}$ was assessed by Thioflavin T assay. $\mathrm{A} \beta_{42}$ recombinant peptide (rPeptide) was resuspended in $1 \%$ $\mathrm{NH}_{4} \mathrm{OH}$ at a concentration of $1 \mathrm{mg} / \mathrm{mL}$. A concentration of $10 \mu \mathrm{M}$ of $\mathrm{rA} \beta_{42}$ was combined with or without different concentrations of each carotenoid (1, 3, 10, and $30 \mu \mathrm{M})$. A volume of $200 \mu \mathrm{L}$ of the mixture was plated in a 96 -well plate. The plate was incubated at $37^{\circ} \mathrm{C}$ for 48 hours. Then, $20 \mu \mathrm{M}$ of Thioflavin $\mathrm{T}$ (Sigma-Aldrich) was added and the fluorescence was measured using a microplate reader (synergy HT BioTek) with a wavelength of $450 \mathrm{~nm}$ for excitation and $485 \mathrm{~nm}$ for emission. Curcumin $(5 \mu \mathrm{M})$ was used as the positive control. All reactions were performed in the presence of $0.1 \%$ of dimethyl sulfoxide, which was used as diluent for the compounds. The half maximal inhibitory concentration $\left(\mathrm{IC}_{50}\right)$ was established by adjusting the sigmoidal dose-response curve following GraphPad Prism 5 procedure.

\section{In silico molecular modeling}

Molecular docking studies with the carotenoids (ligands) were carried out on the fibril structure of $A \beta_{42}$ (PDB ID-2BEG) comprising $5 \mathrm{~A} \beta_{42}$ proteins retrieved from the Protein Data Bank. The simple monomer of the beta-fibril model of $A \beta_{42}$ 
was used as the receptor for docking calculations. Preparation of the target peptides and ligands, visualization of data structures, ligand minimization, and docking analysis were carried out using the CDOCKER protocol in Discovery Studio 3.5 software (Accelrys, San Diego, CA, USA). CDOCKER is a grid-based molecular docking methodology that uses CHARMm force fields. Docking exercises were conducted to critically evaluate the extend of binding of the ligands with $\mathrm{A} \beta_{42}$ and to establish their relative strengths. ${ }^{21}$

\section{Results}

\section{Identification of carotenoids}

Fractionation and isolation of the carotenoids from the extracts of $P$. sapota and A. aculeata fruits were completely achieved by column chromatography using different eluents. Two carotenoids, cryptocapsin and cryptocapsin-5, 6 -epoxide presenting a keto $\kappa$-ring at one end of the molecule, bearing hydroxyl groups, were isolated from the extracts of $P$. sapota fruit. The presence of these carotenoids in $P$. sapota fruit was identified earlier by Murillo et al. ${ }^{20,22}$ On the other hand, zeaxanthin, a carotenoid bearing only $\beta$-ionone hydroxylated rings, was isolated from $A$. aculeata extract. This carotenoid was previously reported in $A$. aculeate fruit. ${ }^{16,23}$ Further purification of the isolated compounds was accomplished by high performance liquid chromatography using a C-30 column. The chemical nature of each carotenoid was fully determined by NMR and MS techniques as described in Supplementary material. The chemical structures of the isolated carotenoids are presented in Table 1.

\section{Anti-amyloidal activity of carotenoids}

In this investigation, Thioflavin $\mathrm{T}$ assay was used to evaluate the anti-amyloidogenic activity of cryptocapsin, cryptocapsin-5,6-epoxide, and zeaxanthin. All the carotenoids studied exhibited bioactivity in a dose-dependent fashion. Cryptocapsin showed higher bioactivity $\left(\mathrm{IC}_{50}=1.97 \mu \mathrm{M}\right)$, while zeaxanthin and cryptocapsin-5,6-epoxide showed comparable bioactivity ( $\mathrm{IC}_{50}$ of $2.29 \mu \mathrm{M}$ and $2.53 \mu \mathrm{M}$, respectively) (Table 1 and Figure $\mathrm{S} 1$ ).

\section{Molecular docking of carotenoids}

In order to get more insights on the anti-amyloidogenic activity of the carotenoids, the molecular interactions by which these compounds inhibit $A \beta$ aggregation were studied by performing molecular modeling. This analysis is based on determination of protein-ligand binding is progressively being used for discovery of new drugs. ${ }^{24}$ So far, there has been no report on the use of molecular modeling for identifying carotenoids as potential $A \beta$ inhibitors. For modeling the
Table I Chemical structures and anti-amyloidal activity of carotenoids
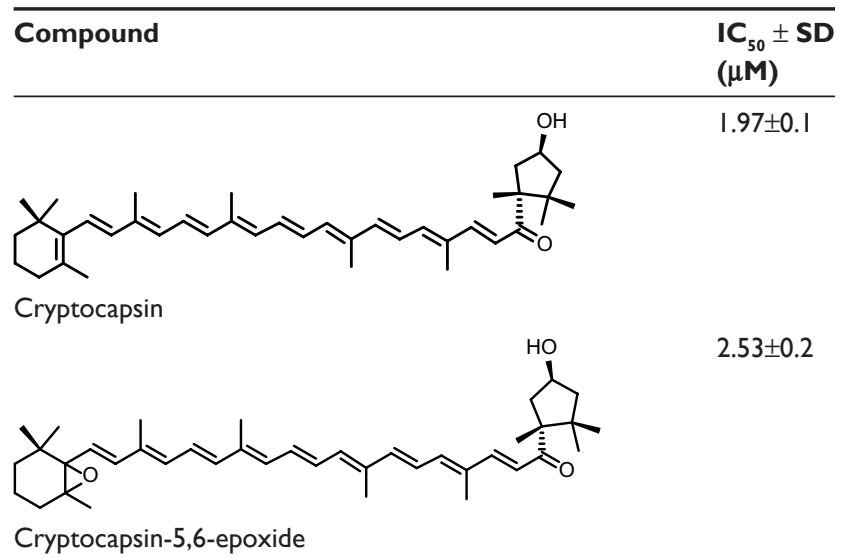

$2.53 \pm 0.2$

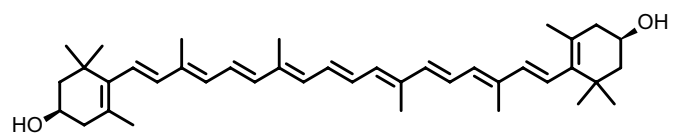

$2.29 \pm 0.2$

Zeaxanthin

Notes: Cryptocapsin and cryptocapsin-5,6-epoxide are carotenoids with a keto $\kappa$-ring at one end on the chemical structure. Zeaxanthin has only hydroxylated $\beta$-ionone rings. $I C_{50}$ results were obtained from three independent experiments performed in duplicates.

Abbreviations: $\mathrm{IC}_{50}$, half maximal inhibitory concentration; SD, standard deviation.

interactions between the protein (receptor) and the ligands, the receptor is held rigid, while the ligands are allowed to flex during the refinement to specify the ligand placement in the binding domain. Ligand energy minimization was carried out in a vacuum, and the peptides were pre-processed separately by energy minimization values. Structural details for $A \beta$ structure and energy-minimized ligands are displayed in Figure 1. $A \beta$ is a short peptide with 42 residues that bears two amyloidic areas, one at sequence 16-21 (amyloidic region 1) and the second sequence at 32-36 (amyloidic region 2). ${ }^{25}$ For this modeling, only residues from 17 to 42 were considered as the amino acid sequence from 1 to 16 is unstructured (Figure 1A).

Investigations of the protein/ligand complex models, represented in Figure 2, were based on three criterions: binding energy, interacting amino acid residues, and bond distance of $A \beta$ protein with each ligand. Results of these docking parameters are tabulated in Table 2.

\section{Discussion}

Carotenoids have the potential to play a significant role in the prevention and treatment of neurodegenerative disorders such as AD. ${ }^{18}$ Investigations of the effect of carotenoids on $A \beta$ plaques formation or disruption are limited. ${ }^{18,26}$ Amyloid aggregation is a key factor in the pathogenesis of $\mathrm{AD}$, thus preventing the polymerization of monomers, and has therapeutic potential. Most of the drug discovery 


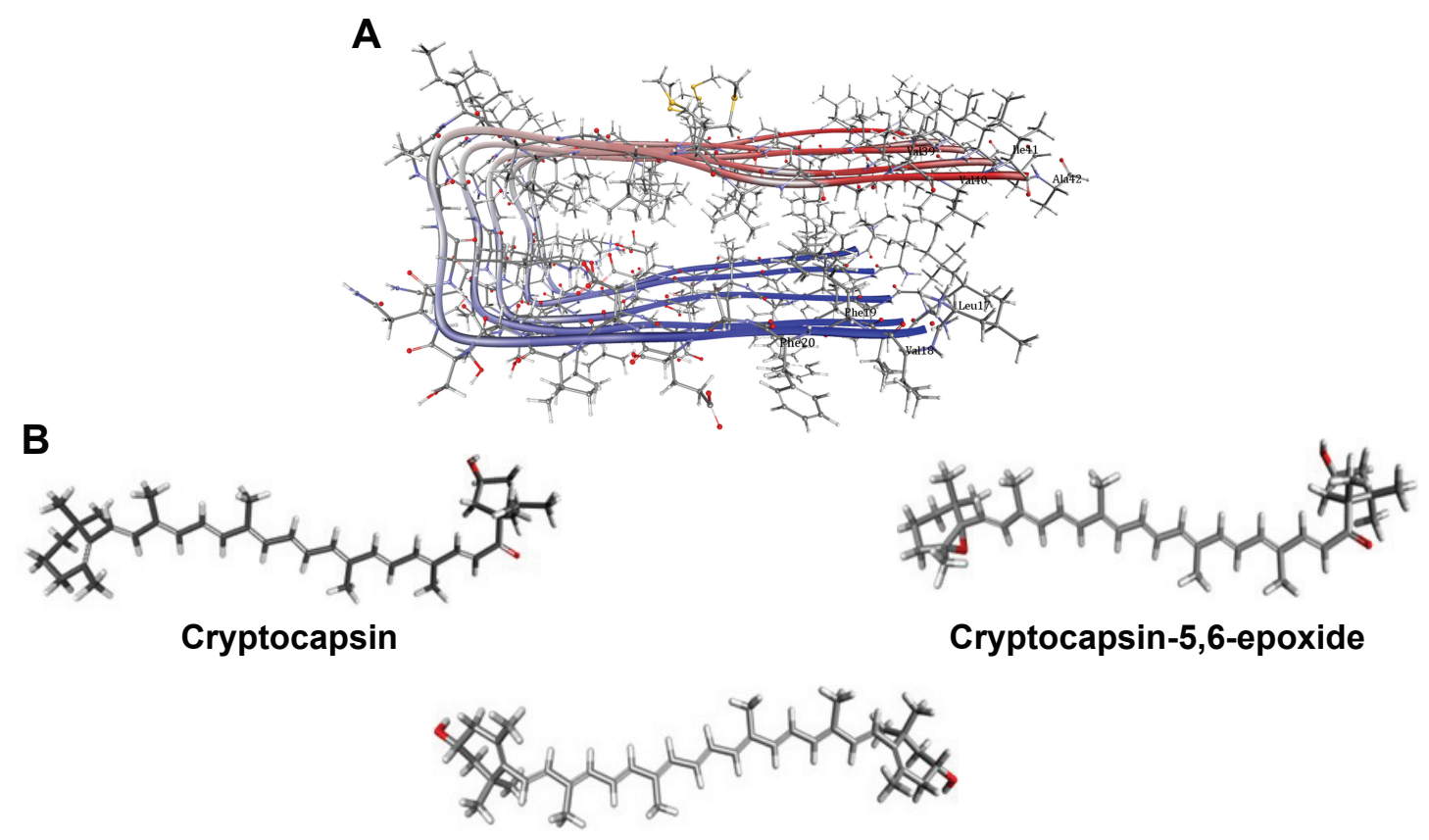

Zeaxanthin

Figure I Optimized chemical structures for docking analysis.

Notes: (A) Three-dimensional structure of $A \beta_{42}$ fibrils. (B) Carotenoids-minimized energy structure used for molecular modeling.

studies are focused on prevention of amyloid aggregation both at preclinical and clinical levels. ${ }^{4}$ Therefore, we studied the anti-amyloidogenic properties of cryptocapsin, cryptocapsin-5,6-epoxide (both keto $\kappa$-ring carotenoids), and zeaxanthin ( $\beta$-ring carotenoid). Thioflavin $\mathrm{T}$ assay showed that all the three carotenoids inhibit $\mathrm{A} \beta$ aggregation in a dose-dependent manner. Molecular modeling was performed for achieving more insights on the possible mechanism of inhibition. The carotenoids here investigated have high bond-free energies (Table 2), which indicates that they bind tightly with $\mathrm{A} \beta_{42}$ inhibiting aggregation, therefore confirming Thioflavin $\mathrm{T}$ assay results. The ketone group
A

A

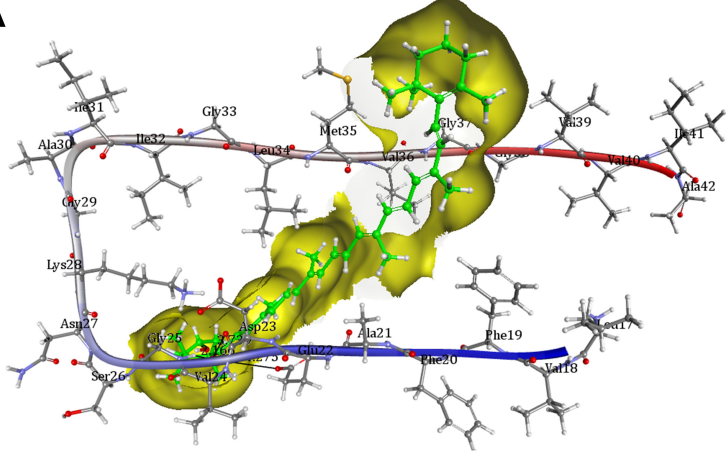

B

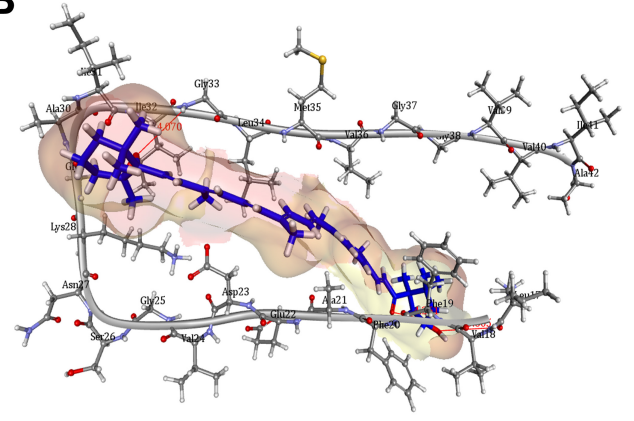

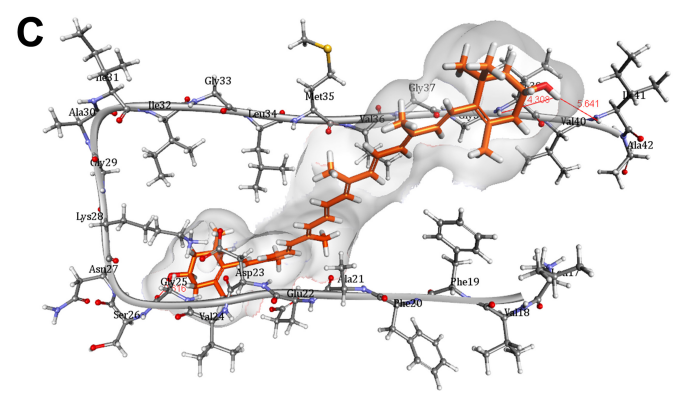

Figure 2 Molecular modeling of interactions of carotenoids and $A \beta_{42}$.

Notes: (A) Cryptocapsin. (B) Criptocapsin-5,6-epoxide. (C) Zeaxanthin. 
Table 2 Docking analysis for interaction of carotenoids with $A \beta$ peptide

\begin{tabular}{llll}
\hline Ligand & $\begin{array}{l}\text { CDOCKER interaction } \\
\text { energy (kcal/mol) }\end{array}$ & $\begin{array}{l}\text { Interaction amino } \\
\text { acid residue }\end{array}$ & Bond distance (A) \\
\hline Cryptocapsin & 37.2329 & Glu22, Asp23, Gly25 & $4.75 ; 3.73 ; 2.16$ \\
Cryptocapsin-5,6-epoxide & 55.2537 & Leul7, Phe 19, Gly33 & $4.659 ; 4.261 ; 4,070$ \\
Zeaxanthin & 79.6585 & Gly25, Val39, lle4I & $2.616 ; 4.308 ; 4.696$ \\
\hline
\end{tabular}

of cryptocapsin forms hydrogen bonds with the peptide at Glu22 and Asp23, while Gly25 interacts with the hydroxyl group of the $\kappa$-ring. Cryptocapsin-5,6-epoxide has a very similar structure with that of cryptocapsin, differing only in the presence of a 5,6 epoxy group in the molecule (Table 1), yet it binds differently to the peptide by interacting with both amyloidic regions of $A \beta$ forming hydrogen bonds at Leu17, Phe19 (amyloidic region 1), and Gly33 (amyloidic region 2). This hydrogen bonding is produced by interaction of the hydroxyl group at the א-ring with Leu17 and the ketone group with Phe19, whereas the epoxy group at the six-membered ring interacts with Gly33. We hypothesize that differences in the structure of these keto $\kappa$-ring carotenoids are key in the mode by which they inhibit the formation of amyloid fibrils. The interactions of ligands, such as cryptocapsin, at no-amyloidic sites of $\mathrm{A} \beta$ have been associated with disruption and disaggregation of the beta-sheet fibril structure. ${ }^{27}$ Moreover, ligands such as cryptocapsin-5,6-epoxide that bind to amyloidic regions prevent association of $A \beta$ inhibiting the formation of betafibril. ${ }^{27}$ Zeaxanthin is a carotenoid that has one hydroxyl group at each $\beta$-ionone ring. One of these hydroxyl groups interacts with two amino acids of $\mathrm{A} \beta$ (Val39 and Ile41), while the hydroxyl group placed on the other $\beta$-ionone ring interacts with Gly25. Neither of these amino acids is present at amyloidic sites; so, it is very likely that this carotenoid may lead to disintegration of beta-fibrils. A earlier study showed that the presence of hydroxyl groups in the chemical structure of carotenoids is crucial for antiamyloidogenic activity. ${ }^{18}$ Further, the polyene backbone in carotenoids inhibits the formation of $A \beta$ fibrils through hydrophobic interactions. ${ }^{18,26}$

The beneficial role of carotenoids to human health due to their therapeutic properties is widely known. ${ }^{17,28}$ There are limited studies on clinical intervention of carotenoids in aging and age-related diseases. ${ }^{17,29}$ In general, the level of carotenoids in food is low. Modest concentrations of zeaxanthin have been found in the serum of individuals consuming a diet rich in corn. ${ }^{30}$ Hence, the potential of zeaxanthin as an agent against $\mathrm{AD}$ is important since these levels would not be achieved by food intake. On the other hand, there is no report in the literature about the concentrations in serum of cryptocapsin and cryptocapsin-5,6-epoxide. This is the first report attributing a biological activity for both carotenoids. At this point, our data, and other studies, indicate preliminary information on the possible beneficial role of carotenoids in AD.

\section{Conclusion}

Healthy aging and related disorders are a growing concern worldwide. Clinical intervention for the prevention or treatment of $\mathrm{AD}$ and other neurodegenerative disorders through nutraceutical molecules is a growing topic. Our study provided evidence that cryptocapsin, cryptocapsin-5,6-epoxide, and zeaxanthin have anti-amyloidogenic potential. The present study provides a clue on the role of novel carotenoids as possible intervention molecules after further preclinical studies in Alzheimer's animal models.

\section{Acknowledgments}

Johant Lakey-Beitia and Deborah Doens are supported by the Institute for Training and Development of Human Resources (IFARHU) and SENACYT (Panama). Johant Lakey-Beitia is also supported by the Ministry of Economy and Finance (DIPRENA-DPIP-10866-2013) on Nutritive Supplements and by Melo Brain Grant (Panama). Armando A Durant-Archibold greatly acknowledges financial support from SENACYT (ECS11-002) and INDICASAT-BID (02-12). Patricia L Fernandez, Enrique Murillo, KS Rao, and Armando A Durant-Archibold would like to acknowledge SENACYT (Panama) and the National System of Investigators for supporting their research.

\section{Disclosure}

The authors report no conflicts of interest in this work.

\section{References}

1. World Health Organization [homepage on the Internet]. Geneva: Dementia, Fact sheet [updated 2016 April; cited 2017 Feb 13]. Available from: http://www.who.int/mediacentre/factsheets/fs362/en/. Accessed February 13, 2017.

2. An SS, Park SA, Bagyinszky E, et al. A genetic screen of the mutations in the Korean patients with early-onset Alzheimer's disease. Clin Interv Aging. 2016;11:1817-1822. 
3. Castellani RJ, Rolston RK, Smith MA. Alzheimer disease. Dis Mon. 2010;56(9):484-546.

4. Blennow K, de Leon MJ, Zetterberg H. Alzheimer's disease. Lancet. 2006;368(9533):387-403.

5. Bu XL, Rao PP, Wang YJ. Anti-amyloid aggregation activity of natural compounds: implications for Alzheimer's drug discovery. Mol Neurobiol. 2016;53(6):3565-3575.

6. Gadad BS, Britton GB, Rao KS. Targeting oligomers in neurodegenerative disorders: lessons from $\alpha$-synuclein, tau, and amyloid- $\beta$ peptide. J Alzheimer's Dis. 2011;24(Suppl 2):223-232.

7. Lakey-Beitia J, Berrocal R, Rao KS, Durant AA. Polyphenols as therapeutic molecules in Alzheimer's disease through modulating amyloid pathways. Mol Neurobiol. 2015;51(2):466-479.

8. Verdile G, Fuller S, Atwood CS, Laws SM, Gandy SE, Martins RN. The role of beta amyloid in Alzheimer's disease: still a cause of everything or the only one who got caught? Pharmacol Res. 2004;50(3):397-409.

9. Rao AV, Balachandran B. Role of oxidative stress and antioxidants in neurodegenerative diseases. Nutr Neurosci. 2002;5(5):291-309.

10. Rubio-Perez JM, Morillas-Ruiz JM. A review: inflammatory process in Alzheimer's disease, role of cytokines. Scientific World Journal. 2012; 2012:756357.

11. Tarozzi A, Morroni F, Merlicco A, et al. Neuroprotective effects of cyanidin 3-O-glucopyranoside on amyloid beta (25-35) oligomerinduce toxicity. Neurosci Lett. 2010;473(2):72-76.

12. Lopez LB, Kritz-Silverstein D, Barret Connor E. High dietary and plasma levels of the omega-3 fatty acid docosahexaenoic acid are associated with decreased dementia risk: the Rancho Bernardo study. J Nutr Health Aging. 2011;15(1):25-31.

13. Ghosh S, Banerjee S, Sil PC. The beneficial role of curcumin on inflammation, diabetes and neurodegenerative disease: a recent update. Food Chem Toxicol. 2015:83:111-124.

14. Hyung SJ, DeToma AS, Brender JR, et al. Insights into antiamyloidogenic properties of the green tea extract (-)-epigallocatechin-3-gallate toward metal-associated amyloid-beta species. Proc Natl Acad Sci U S A. 2013; 110(10):3743-3748.

15. Obulesu M, Dowlathabad MR, Bramchari PV. Carotenoids and Alzheimer's disease: an insight into therapeutic role of retinoids in animal models. Neurochem Int. 2011;59(5):535-541.

16. Murillo E, Melendez-Martinez AJ, Portugal F. Screening of vegetables and fruits from Panama for rich sources of lutein and zeaxanthin. Food Chem. 2010;122(1):167-172.
17. Fiedor J, Burda K. Potential role of carotenoids as antioxidants in human health and disease. Nutrients. 2014;6(2):466-488.

18. Papandreou MA, Kanakis CD, Polissiou MG, et al. Inhibitory activity on amyloid- $\beta$ aggregation and antioxidant properties of Crocus sativus stigmas extract and its crocin constituents. J Agric Food Chem. 2006;54(23):8762-8768.

19. Rodriguez-Amaya DB. A guide to carotenoid analysis in foods. Washington, DC: ILSI Press; 2001.

20. Murillo E, Mclean R, Britton G, Agócs A, Nagy V, Deli J. Sapotexanthin, an A-provitamin carotenoid from red mamey (Pouteria sapota). J Nat Prod. 2011;74(2):283-285.

21. Momany FA, Rone R. Validation of the general purpose QUANTA3.2/ CHARMm force field. J Comp Chem. 1992;13(7):888-900.

22. Murillo E, Turcsi E, Szabó I, et al. Carotenoid composition of the fruit of red mamey (Pouteria sapota). J Agric Food Chem. 2016;64(38): $7148-7155$

23. Murillo E, Giuffrida D, Menchaca D, et al. Native carotenoids composition of some tropical fruits. Food Chem. 2013;140(4):825-836.

24. Jorgensen WL. The many roles of computation in drug discovery. Science. 2004;303(5665):1813-1818.

25. Garbuzynskiv SO, Lobanov MY, Galzitskaya OV. FoldAmyloid: a method of prediction of amyloidogenic regions from protein sequence. Bioinformatics. 2010;26(3):326-332.

26. Ono K, Yoshiike Y, Takashima A, Hasegawa K, Naiki H, Yamada M. Vitamin A exhibits potent antiamyloidogenic and fibril-destabilizing effects in vitro. Exp Neurol. 2004;189(2):380-392.

27. Hetényi C, Körtvélyesi T, Penke B. Mapping of possible binding sequences of two beta-sheet breaker peptides on beta amyloid peptide of Alzheimer's disease. Bioorg Med Chem. 2002;10(5):1587-1593.

28. Álvarez R, Vaz B, Gronemeyer H, de Lera ÁR. Functions, therapeutic applications, and synthesis of retinoids and carotenoids. Chem Rev. 2014;114(1):1-125.

29. Hammond BR. Dietary carotenoids and the nervous system. Foods. 2015;4(4):698-701.

30. Johnson EJ, Hammond BR, Yeum KJ, et al. Relation among serum and tissue concentrations of lutein and zeaxanthin and macular pigment density. Am J Clin Nutr. 2000;71(6):1555-1562. 


\section{Supplementary materials}

Characterization of cryptocapsin, cryptocapsin-5,6-epoxide, and zeaxanthin by nuclear magnetic resonance spectroscopy and mass spectrometry Cryptocapsin

Mass spectrometry (MS) data APCI (+): 568. Nuclear magnetic resonance (NMR) data: ${ }^{1} \mathrm{H}-\mathrm{NMR}$ cryptocapsin (400 MHz, $\mathrm{CDCl}_{3}$ ): $\delta 0.84\left(3 \mathrm{H}, \mathrm{s}, \mathrm{CH}_{3}-16^{\prime}\right), 1.03$ (6 H, s, H-16, H-17), 1.21 (3 H, s, H-17'), 1.37 (3 H, s, H-18'), 1.47 ( $2 \mathrm{H}, \mathrm{m}, \mathrm{H}-2), 1.48\left(1 \mathrm{H}, \mathrm{m}, \mathrm{H}_{\mathrm{ax}-4^{4}}\right), 1.57$ ( $\left.\mathrm{m}, 1 \mathrm{H}, \mathrm{H}_{\mathrm{eq}-2^{2}}\right), 1.62$ (2 H, m, H-3), 1.68 (3 H, m, H $\left.{ }_{\mathrm{ax}-2^{\prime}}, \mathrm{H}-3^{\prime}\right), 1.71$ (3 H, s, H-18), 1.96 (3 H, s, H-19), 1.97 (6 H, s, H-20, H-19'), 1.98 (3 H, s, H-20'), 2.03 ( $2 \mathrm{H}, \mathrm{H}-4, J=6 \mathrm{~Hz}), 2.52$ ( $\left.1 \mathrm{H}, \mathrm{m}, \mathrm{H}_{\mathrm{eq}-4^{\prime}}\right), 4.51$ (1 H, m, H-3'), 6.14 (1 H, H-8), 6.17 (1 H, H-7), 6.18 (1 H, d, H-10, J =13 Hz), 6.27 (1 H, d, H-14), 6.34 (1 H, d, H-14', $J=11 \mathrm{~Hz}$ ), 6.35 (1 H, d, H-12, J=14 Hz), 6.48 (1 H, d, H-7', $J=15 \mathrm{~Hz}), 6.53$ ( $\left.1 \mathrm{H}, \mathrm{d}, \mathrm{H}-12^{\prime}, J=16 \mathrm{~Hz}\right), 6.56(1 \mathrm{H}$, d, H-10' $J=11.0$ ), 6.62 (2 H, m, H-15, H-15'), 6.63 (1 H, m, H-11'), 6.66 (1 H, m, H-11), 7.32 (1 H, d, H-8', $J=15 \mathrm{~Hz}$ ) parts per million (ppm). ${ }^{13} \mathrm{C}-\mathrm{NMR}\left(100 \mathrm{MHz}, \mathrm{CDCl}_{3}\right)$ : $\delta 12.8,12.9,13.0,19.3,21.4,21.9,25.2,26.0,27.1,29.1$, 29.8, 33.2, 34.4, 39.7, 44.1, 45.4, 49.6, 50.9, 59.1, 70.5, $72.9,120.9,124.1,125.8,129.6,130.3,130.8,131.8,133.7$, $135.4,135.9,136.6,137.1,137.8,138.0,140.8,142.1,147.0$, $203.0 \mathrm{ppm}$.

\section{Cryptocapsin-5,6-epoxide}

MS data APCI (+): 584. NMR data: ${ }^{1} \mathrm{H}-\mathrm{NMR}$ cryptocapsin5,6-epoxide (400 MHz, $\mathrm{CDCl}_{3}$ ): $\delta 0.83\left(3 \mathrm{H}, \mathrm{s}, \mathrm{CH}_{3}-16^{\prime}\right), 0.93$
(3 H, s, $\left.\mathrm{CH}_{3}-17\right), 1.04\left(1 \mathrm{H}, \mathrm{m}, \mathrm{H}_{\mathrm{ax}-2}\right), 1.10\left(3 \mathrm{H}, \mathrm{s}, \mathrm{CH}_{3}-16\right)$, 1.14 (3 H, s, $\left.\mathrm{CH}_{3}-18\right), 1.21\left(3 \mathrm{H}, \mathrm{s}, \mathrm{CH}_{3}-17^{\prime}\right), 1.37$ (3 H, s, $\left.\mathrm{CH}_{3}-18^{\prime}\right), 1.43(1 \mathrm{H}, \mathrm{m}, \mathrm{H}-3), 1.49\left(1 \mathrm{H}, \mathrm{m}, \mathrm{H}_{\mathrm{ax}-4^{\prime}}\right), 1.50(1 \mathrm{H}$, $\left.\mathrm{m}, \mathrm{H}_{\mathrm{eq}-2}\right), 1.70\left(1 \mathrm{H}, \mathrm{m}, \mathrm{H}_{\mathrm{ax}-2^{2}}\right), 1.72\left(1 \mathrm{H}, \mathrm{m}, \mathrm{H}_{\mathrm{ax}-4}\right), 1.89(1 \mathrm{H}$, m, $\left.\mathrm{H}_{\text {eq- } 4}\right), 1.94$ (3 H, s, $\left.\mathrm{CH}_{3}-19\right), 1.96$ (3 H, s, $\left.\mathrm{CH}_{3}-19^{\prime}\right), 1.98$ (6 H, s, Me-20, 20'), 2.01 (1 H, m, $\left.\mathrm{H}_{\text {eq- } 2^{\prime}}\right), 2.95$ (1 H, dd, Heq-4', $J=15,9$ Hz), 4.51 (1 H, m, H-3'), 5.90 (1 H, d, H-7, $J=15 \mathrm{~Hz}), 6.19$ (1 H, d, H-10, $J=11 \mathrm{~Hz}), 6.27$ (1 H, m, H-14); 6.29 ( $1 \mathrm{H}, \mathrm{d}, \mathrm{H}-8, J=15 \mathrm{~Hz}), 6.34$ (1 H, m, H-14'), 6.37 (1 H, d, H-12, $J=15 \mathrm{~Hz}), 6.44$ (1 H, d, H-7' $J=15 \mathrm{~Hz}), 6.51(1 \mathrm{H}$, d, H-12', $J=15 \mathrm{~Hz}$ ), 6.56 (1 H, d, H-10', $J=11 \mathrm{~Hz}), 6.61$ (1 H, m, H-11' $J=11 \mathrm{~Hz}), 6.63$ (1 H, d, H-11), 6.65 (1 H, m, H-15), 6.69 (1 H, m, H-15'), 7.32 (1 H, d, H-8', J=15 Hz) ppm. ${ }^{13} \mathrm{C}-\mathrm{NMR}\left(100 \mathrm{MHz}, \mathrm{CDCl}_{3}\right)$ : $\delta 12.7,12.8,13.0,17.1$, 21.1, 21.3, 25.1, 25.9, 26.0, 30.1, 33.1, 34.8, 35.7, 44.0, 45.3, $50.8,58.9,65.5,70.4,71.4,120.9,124.1,124.4,125.3,129.8$, 131.6, 131.8, 132.5, 133.7, 134.9, 135.2, 136.0, 137.2, 137.5, $137.8,140.7,142.0,146.9,202.9 \mathrm{ppm}$.

\section{Zeaxanthin}

MS data APCI (+): 569. NMR data: ${ }^{1} \mathrm{H}-\mathrm{NMR}$ zeaxanthin (400 MHz, $\left.\mathrm{CDCl}_{3}\right): \delta 1.04\left(12 \mathrm{H}, \mathrm{s}, \mathrm{CH}_{3}-16^{\prime}, \mathrm{CH}_{3}-17^{\prime}\right.$, $\left.\mathrm{CH}_{3}-16, \mathrm{CH}_{3}-17\right), 1.71$ (6 H, s, Me-18', Me-18), 1.98 (s, Me-19, Me-20, Me-19', Me-20'), 2.02 (m, H-4', H-4), 2.39 (2 H, dd, H-4, H-4'), 4.01 (2 H, m, H-3, H-3'), 6.06-6.18 (m, H-7, H-7', H-8, H-8', H-10, H-10'), 6.24-6.30 (m, H-14, H-14'), 6.37 (d, H-12, H-12' $J=15$ Hz), 6.54-6.67 (m, H-11, $\left.\mathrm{H}-11^{\prime}, \mathrm{H}-15, \mathrm{H}-15^{\prime}\right)$ ppm. ${ }^{13} \mathrm{C}-\mathrm{NMR}\left(\mathrm{CDCl}_{3}, 100 \mathrm{MHz}\right) 12.7$, $12.8,21.5,29.2,29.7,37.1,42.5,48.3,65.0,125.4,125.5$, $126.1,130.0,131.2,132.5,137.5,137.7,138.4 \mathrm{ppm}$.
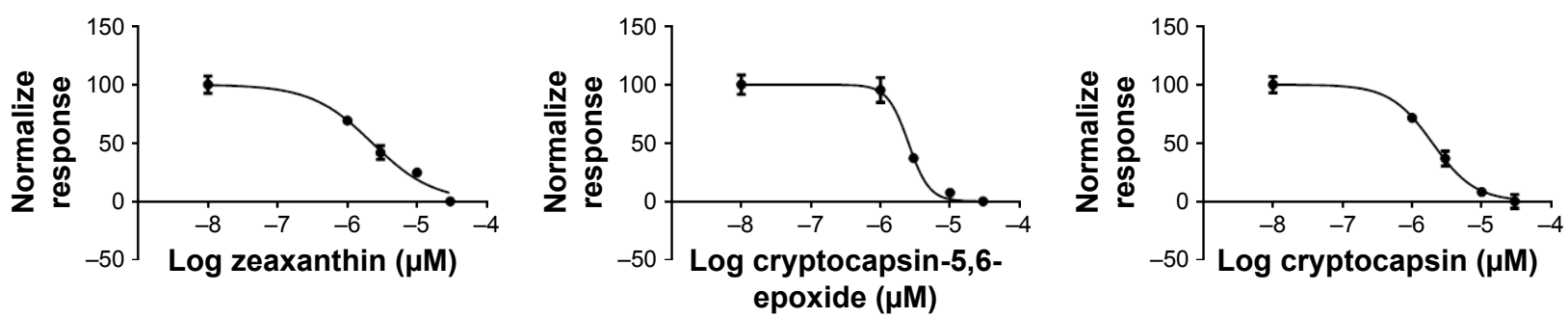

Figure SI Carotenoids inhibit $A \beta$ aggregation.

Notes: $\mathrm{IC}_{50}$ sigmoidal curves calculated by the statistical software package GraphPad Prism 6 from the active compounds. Graphs represent the sigmoidal curves for the IC calculation of a representative experiment. Results represent mean \pm SD from samples assayed in duplicates. Abbreviations: $\mathrm{IC}_{5}$, half maximal inhibitory concentration; $\mathrm{SD}$, standard deviation. 


\section{Publish your work in this journal}

Clinical Interventions in Aging is an international, peer-reviewed journal focusing on evidence-based reports on the value or lack thereof of treatments intended to prevent or delay the onset of maladaptive correlates of aging in human beings. This journal is indexed on PubMed Central, MedLine,

CAS, Scopus and the Elsevier Bibliographic databases. The manuscript management system is completely online and includes a very quick and fair peer-review system, which is all easy to use. Visit http://www.dovepress. com/testimonials.php to read real quotes from published authors. 